\title{
Radio
}

\section{Structure and efficiency aspects of FM transmission}

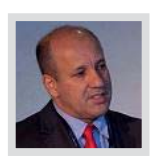

Moderator: José Mauro De Ávila

Diretor técnico / Mega Sistema de Comunicação / SET

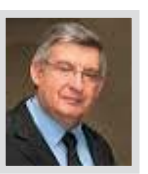

Sistemas Irradiantes - Influência das Torres e Estruturas nos Diagramas das Antenas.

Speaker: José Roberto Elias

Gerente Comercial na IF Telecom

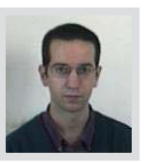

Eficiência dos transmissores de radio refrigerados por liquido. Descrição e analise do custo total de operação.

Speaker: Gabriel Palmieri

Sales Manager Latin America / GatesAir

Torres Metálicas. Tipos de estruturas. Legislação Municipal Speaker: Rodrigo Oliveira

Diretor Comercial na STM Brasil - Soluções em Torres Metálicas.

Tecnologia LED em torres de radiodifusão e Normativas de sinalização. Speaker: Michel Antonio Rodini

Gerente técnico na Prod. Eletr. FRATA/Professor ETEC Albert

Einstein/Representante da direção no sistema da qualidade ISO 9001 


\section{Radio}

\section{STRUCTURE AND EFFICIENCY ASPECTS OF FM TRANSMISSION}

Moderator: José Mauro de Ávila

Technical Director at Mega Sistema de Comunicação / SET

- Radiant systems - Influence of towers and structures in the antenna diagrams. Speaker: José Roberto Elias

Commercial Manager at IF Telecom

- Efficiency of the radio transmitters cooled by liquid. Description and analysis of operation total cost .

Speaker: Gabriel Palmieri

Sales Manager Latin America / GatesAir

- Metal towers. Types of structures. Municipal legislation.

Speaker: Rodrigo Oliveira

Commercial Director at STN Brazil STM - Solutions in Metal Towers.

Scaling a vertical structure. Key aspects of project. Warranty and ART, Maintenance (preventive and corrective).

- Tecnologia LED em torres de radiodifusão e Normativas de sinalização.

Speaker: Michel Antonio Rodini

Gerente técnico na Prod. Eletr. FRATA/Professor ETEC Albert Einstein/Representante da direção no sistema da qualidade ISO 9001 


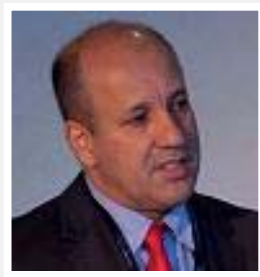

\section{JOSÉ DE MAURO ÁVILA}

Technical Director - Mega Communication System / SET

Electrical Engineer and Occupational Safety Engineer from Paulista University in 2008.

Qualified as an electronics technician from the Moura Lacerda institution 1982.

A regular participant at NAB - Broadcast Engineering Conference since 1992. Performs at different seminars of Brazilian entities engaged in the sector, such as AESP, SET and ABERT. Broadcast Electronics - Product Training Seminar - Audio Vault Administrator/VAR Sales - 1999/2000/2002/2006/2013. Harris Corporation - Emphasis: Harris HT 35FM transmitter - 1991. He is also currently deputy Leader of the AESP Technical Committee and continues to work in technical support for Broadcast Electronics in Brazil in the case of automation systems.

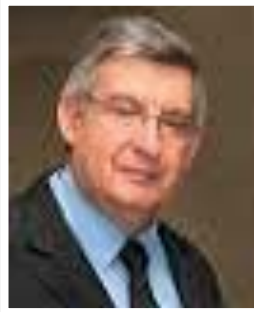

\section{JOSE ROBERTO ELIAS}

Sales Manager - IF TELECOM

With a degree in Electronic Engineering from UNICAMP in 83, and an MBA from the FGV in 2005, he has vast experience in Brazilian and multinational companies in the fields of Telecommunications and Broadcast. He currently holds the position of Sales Manager at IF Telecom, and is also a Professor at the Fluminense Federal University on the MBA course in Irradiant Systems and Digital Encoding.

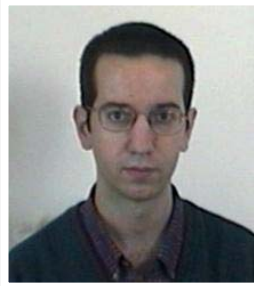

\section{GABRIEL PALMIERI}

Solution Architect - GatesAir

Since 2010, he is working at GatesAir pre-sales area, designing solutions for radio and TV networks. Previously from 1999, he conducted pre-sales at Harris Microwave division.

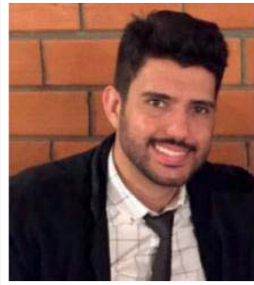

\section{RODRIGO OLIVEIRA}

Sales Director - STM Brazil

He completed a technical course in Industrial Process Management at the SENAI, in 2007. He has an Undergraduate Degree in Business Administration from UNOPAR, concluded in 2011. A graduate degree in Business Planning and Management from PUC, concluded in 2014. In 2015, he completed the SENAI AutoCAD course.

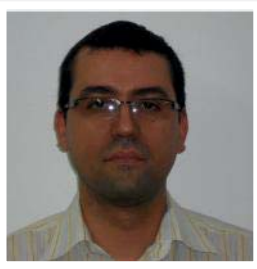

\section{MICHEL ANTONIO RODINI}

Gerente técnico na Prod. Eletr. FRATA/Professor ETEC Albert Einstein/Representante da direção no sistema da qualidade ISO 9001

Mestre em engenharia elétrica - UFABC sendo o responsável técnico no projeto de sistemas ópticos utilizando LEDs de alta potência para sinalização aeronáutica em Torres Anemométricas, Torres de Telecomunicações e Aerogeradores . Responsável pela Qualificação de equipamentos junto INMETRO, IPT, IEE, LIT e professor na Etec Albert Einstein. 